\title{
A EMPRIAgUEZ DA VÍtima NA ETIOLOGIA DO DELITO
}

\author{
J. Madeira Neves \\ Professor de Medicina Legal da Faculdade de Di- \\ reito de Santa Catarina
}

Muito numersos os estudos que já foram feitos e publicados, concernentes ao estado de embriaguez do agente criminoso, por ocasião de cometer sua ação anti-social. Todos os códigos penais, práticamente, focalizam, também, essa eventualidade, em dispositivos que ora acentuam, ora minoram a responsabilidade criminal do agente. Pouco, há, portanto, já agora, a acrescentar sôbre essa matéria.

Mas, se a embriaguez do agente assim tem sido pesquisada e ressaltada - em todos os seus graus e modalidades existe uma recíproca que, quanto se me afigura, não parece suficientemente debatida e esmiuçada pelos autores de criminologia. Quero reportar-me ao estado de embriaguez da própria vítima, estado que, por sua mesma natureza, haveria constituido o fator único ou preponderante no eclodir da crise delituosa.

Devemos dizer, em primeiro lugar, que a circunstância existe, e bem líquida. Autores diversos já a enumeraram, não lhe atribuindo ,todavia, o porte e o realce que bem merece pela frequência e validez de sua participação.

Assim, o inglês Mark Benny, em seu livro Low Company, acentua que pessoas embriagadas constituem prêsa fácil em muitas formas de crime econômico.

É observação corriqueira que os batedores de carteiras insinuam-se, de preferência, junto aos bares e à saída de grandes festas. 
Conhecem-se casos em que o estado de embriaguez de um marido brutal, levado ao estupor, fez com que a espôsa, momentâneamente em superioridade - o tivesse assassinado.

Charles Kingston, americano, em seu trabalho Law Breakers, refere observações em que apenas três copos de cerveja tornaram a vítima quase indefesa. Menciona ainda, o famoso caso Polomer, no qual um alcóolatra inveterado poude ser induzido, com tôda facilidade, a fazer grande seguro de vida em proveito de um irmão médico, que o eliminava, insidiosamente, com veneno.

O estudo mais completo de que tenho notícia, nêsse setor, foi o realizado pelo Instituto de Medicina Legal de Belgrado, na Iugoslávia, entre os anos de 1924 - 1933, e mais tarde publicado por M. Nilovanic, numa revista alemã de criminologia.

Havia comprovação de sinais de alcoolismo recente em $9 \%$ das 55 vítimas de homicídio doloso, e em $74 \%$ das 159 vítimas de homicidio culposo.

Claro está que nem sempre a condição de embriaguez, por ocasião da morte, poderá ser evidenciada, posteriormente, ao se fazer a autopsia; além disso, processos patológicos diversos, coexistentes, podem mascarar as pesquisas, entre êles a diabete, a tuberculose progressiva, o morfinismo, o cocainismo, etc.

Dessa maneira, as cifras antes expostas deviam ser havidas como representando uma realidade deturpada para menos. De todos os indivíduos do sexo masculino mortos, práticamente dois terços teriam feito uso recente de alcool.

Que haja tanta disparidade entre os resultados de crimes dolosos e culposos, entende-se, pois os últimos sucedem, com maior facilidade, após rixas, discussões as mais fúteis, e elas surgem e se agudizam se se houver feito consumo de álcool.

Por isto mesmo, a ocorrência acentuda de atuações antisociais nos lugares onde exista venda franca de bebidas alcoólicas, tais como, em meu Estado, nos botequins, clubes, salões de bailes públicos, raias de corridas de cavalos, etc. 
Entre 100 homicidas, cujas vidas pregressas e atuações criminosas estudei, em Santa Catarina, 14 cometeram a falta dentro de vendas e botequins; 10 o fizeram em salão de baile público; 4 em raias de corridas de cavalhos. No seu conjunto, somam 28 os sentenciados nessas condições.

Entre os que cometeram lesões corporais - num total de $20-7$ agiram em vendas, $3 \mathrm{em}$ bailes e $3 \mathrm{em}$ festas de igrejas. Evidentemente, as festas de igrejas, nêste caso, são as chamadas "barraquinhas", onde se mercadeiam prendas e bebidas, doadas pelos fiéis, para com o produto ampliarem as instalações religiosas. Recordo-me, também dum processo antigo, apreciado no Conselho Penitenciário, em que numa festa escolar procedeu-se à venda de bebidas alcoólicas, tendo, como resultado a morte de uma criança e de dois adultos...

Vê-se, pois, do acima exposto, que, dentre os homicidas, $28 \%$ das faltas foram efetuadas em locais onde o consumo de álcool era presumível, tanto pelo agente como por sua vítima, e que êsse percentual sobe a 65 - ou práticamente $2 \mid 3$ dos casos - entre os sentenciados - por lesões corporais.

No interrogatório que procedí, sôbre êsses delinquentes, quando já recolhidos à Penitenciária do Estado, verifiquei que a condição de embriaguez da vítima como fator desencadeante da ação delituosa era mencionada por 12 dos homicidas e por 4 dos condenados por lesões corporais, ou sejam percentuais de 12 e 20, respectivamente, para os grupos específicos.

Simultâneamente, uma condição de embriaguez própria como elemento essencial na crise anti-social figurava nas declarações de 15 homicidas e de 6 sentenciados por lesões corporais, com percentuais de 15 e 30 , respectivamente.

Em se somando todos os delinquentes contra a pessoa estudados - ou seja um total de 120 - havia a constatação de 16 casos em que a embriaguez da vítima era assinalada como fator causante do crime, num percentual de 13. Ao mesmo tempo, 21 depoimentos narravam a embriaguez própria, ou um percentual de 17,5 . 
Essa condição de embriaguez da vítima não foi mencionada pelos 130 outros sentenciados por mim inquiridos, e distribuidos da seguinte forma pelos diversos títulos do Código Penal: contra o patrimônio, 102 ; contra a fé pública, 2 ; contra os costumes, 25 ; contra a incolumidade pública, 1 . Entretanto, o estado de embriaguez própria figurava nas declarações de 31 dêsses criminosos.

Assim, no total de 250 sentenciados que estudei, atribuiuse à embriaguez da vítima a causa principal do crime em 16 casos, ou seja em $6,4 \%$, enquanto à embriaguez própria se dava como responsável em 52 das ações anti-sociais, ou seja um percentual de 20,8, três vezes maior, aproximadamente, do que $o$ anterior.

Evidentemente, as cifras que apresento não devem ser tomadas como representativas de uma verdade plena, pois os quesitos concernentes à embriaguez participavam de meu estudo sôbre o perfil sociológico de $\mathbf{2 5 0}$ sentenciados catarinenses, como dois apenas dentre 70 outros. Não houve, pois, de minha parte, qualquer preocupação especial em esmiuçar essa condição.

Seria, também, êrro - reconheço - pretender tirar conclusões mais positivas de simples respostas de sentenciados, por mais escorreitas que fossem, e controladas, embora, por informações doutras fontes de coleta.

Aliás, assinale-se, essas respostas e mais as informações outras que busquei - nos prontuários e nas mesmas zonas de origem dos presos - constituiriam de qualquer maneira quase todo o alicerce possível para se basear estudo dessa ordem, em meu Estado. É que a verificação necroscópica - salvo na Capital - ainda se efetua de modo o mais sumário e discutível, praticada em muitos casos por indivíduos para tanto sem as necessárias credenciais.

Abordando o assunto, quiz apenas ressaltar um aspecto da criminogênese em regra de somenos focalizado, mesmo pelos melhores autores, e, destarte, promover novos estudos e pesquisas nêsse sector tão importante da criminogenese. 
RESUMO - 0 autor apresenta a questão da embriaguez da vítima por ocasião do ato anti-social. Mostra como êsse elemento criminogenético não é, em geral, ressaltado com a importância devida pelos autores. Depois de apresentar dados colhidos na literatura estrangeira, exibe o autor dados seus, originais, obtidos em estudo feito sôbre a atuação delituosa de 250 sentenciados catarinenses. A condição constatou-se sómente nas vítimas de delitos contra a pessoa, atingindo, no grupo, um percentual de 13,33, e no total de 250 sentenciados não ultrapassando o de 6,40 , números sensívelmente menores do que se calcularam, em idênticas condições, para os que assinalaram a embriaguez dos agentes no momento da execução do delito. 